\title{
Efficiency and profitability along the lifecycle stages of small enterprises
}

\section{Csaba Bálint Illés*, Hilda Hurta and Anna Dunay}

Department of Business Economics and Management, Faculty of Economics and Social Sciences, Szent István University, H-2100 Gödöllő, Páter Károly u. 1, Hungary

Email: illes.b.csaba@gtk.szie.hu

Email: hurta.hilda@gtk.szie.hu

Email: dunay.anna@gtk.szie.hu

*Corresponding author

\begin{abstract}
The Adizes lifecycle model is a widely used model for determining the different development stages of enterprises. Lifecycle stages may be differentiated even in the smallest companies, and the model may be used in analyses before making plans and can be a practical tool for managers in the decision-making process. We conducted an overall survey among Hungarian SMEs in 2012, and examined the different attitudes and behaviour of managers in different lifecycle stages of their companies and the most important motivations and driving forces of their decisions in the specific stages. Firstly, we analysed the financial performance of enterprises according to the results of their balance sheet, by which we determined four main categories depending on their business success. Our results proved that the profitability of enterprises is strongly influenced by their lifecycle stage and the growing process is also determined by the age of the enterprise.
\end{abstract}

Keywords: SMEs; lifecycle stages; profitability; growth; competitiveness; Greiner's growth model; Adizes's model; Hungarian enterprises.

Reference to this paper should be made as follows: Illés, C.B., Hurta, H. and Dunay, A. (2015) 'Efficiency and profitability along the lifecycle stages of small enterprises', Int. J. Management and Enterprise Development, Vol. 14, No. 1, pp.56-69.

Biographical notes: Csaba Bálint Illés is Full Professor and Head of the Department of Business Economics and Management at Szent István University Gödöllö, Hungary. His research interest is in the field of business economics, management and development of SMEs, corporate competitiveness, farm management and food safety management.

Hilda Hurta is a Lecturer at Szent István University Gödöllö, Hungary. Her main research fields are microeconomics, business economics, management and competitiveness of small and medium enterprises, managerial attitudes and development of social capital.

Anna Dunay is an Associate Professor at the Szent István University Gödöllö, Hungary. Her main research fields are management and competitiveness of small and medium enterprises, lifecycle analysis of enterprises, competitiveness of the agricultural sector and the food chain, farm management, evolution and implementation of the common agricultural policy. 
This paper is a revised and expanded version of a paper entitled 'Competitiveness of Hungarian small and medium enterprises along their lifecycle' presented at MakeLearn 2014 Conference, Portoroz, Slovenia, 25-27 June 2014.

\section{Introduction and literature review}

Lifecycle models describe the different stages of corporate life. Enterprises are grown and developed according to a natural lifecycle. All organisations have a lifecycle and they undergo predictable and repetitive behaviour patterns as they grow and develop. At each new stage of development, an organisation is facing different challenges. How well or how poorly can the management answer the challenges that will establish their future, the success or failure of the organisation?

Lifecycle models show the life stages of the enterprises and organisations as a sequence of different stages, which are absolutely based on each other. These models not only determine the general features of the different stages, but also summarise the different operational and managing problems of each stage. Lifecycle models are a widely used tool or method that may help the enterprises to handle the transition periods more easily are also taken into consideration by them.

There are different types of development models in the international literature. The model of Timmons includes five stages: the pre-start up (or incubation stage), the Start up and survival, early growth period, maturity stage and stability (or harvest stage). This model does not deal with the declining stage or the death of the enterprises (Timmons, 1990).

Figure 1 Model of Greiner

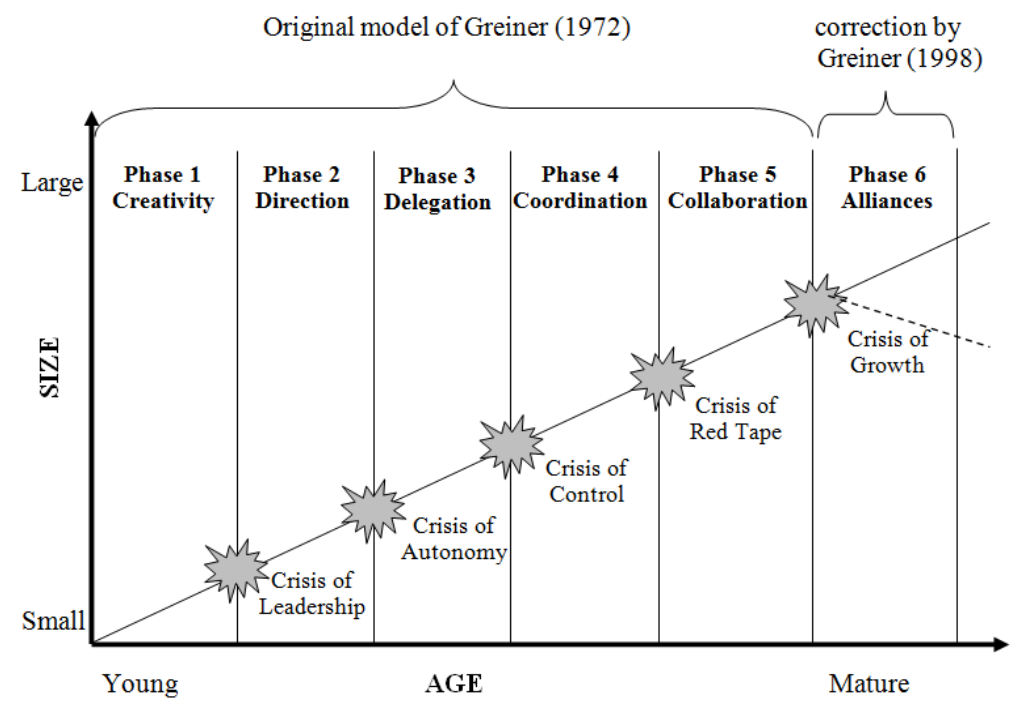

Source: Own construction based on Greiner $(1972,1998)$ and Miskolczi

(2012) 


\subsection{Greiner's growth model}

Greiner (1998) has determined five distinguishable phases in which a growing organisation moves: creativity, direction, delegation, coordination, and collaboration. In each phase, there is an effect of the previous phase and the cause for the next phase. According to Greiner's opinion, the future of an organisation may be less determined by outside forces than it is by the organisation's history. In Greiner's model, corporate lifecycle is depending on the age and the size of companies (see Figure 1).

Greiner's organisational growth model is accepted as a classic in organisation literature. The model is an easy and clear concept, which describes the different phases of organisational growth through evolutionary problems and using revolutionary solution approaches. More than 40 years after its formulation, it is a widely used analysing and managerial tool. Greiner's model describes the phases that organisations go through as they grow. The model distinguishes two basic periods during the growth: evolution and revolution. Evolution is a period of relatively stable growth, which is followed by a 'crisis' - or in other words: revolution - when major organisational change is needed if the company is to carry on growing. These two periods are changing through the lifecycle of the organisation, when the company can go across the crises, it may enter to the new stage, if fails, then it will remain in the former stage, or even terminates. Greiner originally proposed this model in 1972 with five phases of growth, but later, he added a sixth phase, which was first published in Harvard Business Review, in May 1998.

In the first phase, creativity plays the leading role. The enterprise starts its lifecycle and concentrates for the first problems. The first success motivates the management to go further; therefore, the development in this stage is very spectacular. The entrepreneurs/ managers are very busy in creating products and opening up markets. They have not many employees therefore they use informal communication channels. However, as more staff joins the organisation, production expands and capital is injected, there is a need for more formal communication. This phase ends with a leadership crisis, where professional management is needed. The founders must change their style and take on the leader's role, but often someone new person will be brought in.

In the second phase, the new management puts the managerial approach and tasks in the front. Professional managers know more about planning and tactics and renew the situation by strategic thinking and operation plans. This stage also includes separation of activities such as budgeting and marketing, although these are probably not yet done by a separate department. The rules of managing the company are established by the leaders, they determine the coordination tasks, the division of labour, and the structure of the work and direction. The problem arises from the complexity of the work: when the products and processes become so numerous that one person is not enough to manage them all. More managers at different levels may have more or less autonomy, and this situation may be turned into conflicts. The greatest problem is the lack of time and working capacity will be the most important bottleneck in this stage. This phase ends with an autonomy crisis: new structures based on delegation are called for. 
If the company is able to delegate the tasks and responsibility to the appropriate persons, they may enter to the third stage: delegation. This is the response to the autonomy crisis, to divide and establish a greater structure and deeper hierarchy, where individual departments and operational units have individual managers and are delegated greater autonomy. In this stage, the middle managers appear, running multiple operational units and they manage managers rather than give direct orders to the front line. The problems in delegation are connected to the communicated requirements, which are not always understood. Not knowing enough about what is really going on at the bottom of the organisation, the middle and senior managers at the end of this stage start to lose control over everyday operations, and - as a result of the situation - the costs may increase as well, generating a possible financial problem. This phase ends with a control crisis, when a much more sophisticated head office function is required, and the separate parts of the business need to work together.

If the company may pass the control crises successfully, it enters to the fourth phase, when the control plays the leading role. The response to the loss of control is to put additional effort into reporting up and communicating in all directions. The formerly isolated business teams and product organisations are joined up in business units and other collective organisations and became under a centralised direction. Investment finance is allocated centrally; incentives are shared through company-wide profit share schemes aligned to corporate goals. Eventually, though, work becomes submerged under increasing amounts of bureaucracy, and growth may stop. This coordination may bring problems because of the increasing reporting and control adds layers of bureaucracy at all levels. This phase ends on a red-tape crisis: a new culture and structure must be introduced.

The fifth stage may be brought by collaboration. Collaboration may help in building the common future and problem solving. While a collaborative organisation is better in many ways than previous forms, there are now problems in how to grow further without overloading current systems and processes. Structures may be implemented to connect people in multiple dimensions, such as the use of matrix management. This phase ends with a crisis of internal growth. Further growth can only come by developing partnerships with complementary organisations.

In 1998, because of the visible problems and new directions of large, international companies, Greiner added a new stage to the original model for extra-organisational solutions. According to Greiner's idea of, sixth phase suggests that growth may continue through merger, outsourcing, networks and other solutions involving other companies. There is no doubt, there are crises beyond this phase, but Greiner's model does not discuss them.

\subsection{The model of Adizes}

Another concept of the lifecycle of enterprises was described by Adizes. The model of Adizes (1992) introduces the different stages of the lifecycle compared to the human life stages, but the stages of development are shown independently from the size and the age of the organisation (see Figure 2). The model's most important feature is that it gives the most serious problems and threats, which may endanger the enterprise of the given stage. 
Figure 2 The original lifecycle model of Adizes

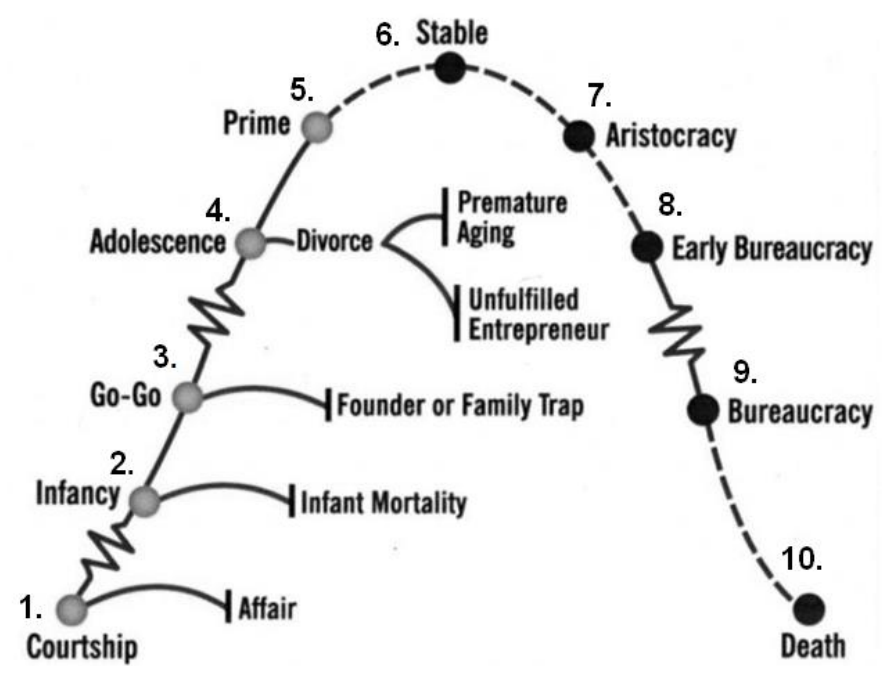

Source: http://adizes.com/corporate_lifecycle.html

According to Adizes, the development of enterprises is influenced by the manageability and controllability of the organisation, and by its flexibility and its ability for renewal. According to his model, the manageability of the enterprises is growing gradually along the lifecycle, and it decreases suddenly at the end of the lifecycle, while flexibility is decreasing gradually.

The Adizes model emphasises that company leaders shall be able to recognise the difference between the conventional problems of a given lifecycle phase of the organisation and those unconventional and harmful problems that may lead to a crises or the total fall of the company. According to Adizes, conventional problems may be solved by the internal resources of the organisation if these problems may be foreseen, while the solution of unconventional problems or dysfunctions need an external help in every cases. The special character of the model of Adizes is that it also refers to the possible death of the enterprises.

\subsection{Lifecycle of Hungarian SMEs}

The economic and political environment may influence the features of the development stages of enterprises; a special example for this phenomenon could be observed in Central European Countries after the political and economic transition process of the 1990s.

The Hungarian researcher, Salamonné (2006) combined the concepts of Adizes and Greiner. This idea was based on a research that was conducted among 50 Hungarian SMEs, which were established between 1989 and 1994. In the research, the special features of Hungarian small and medium enterprises were taken into consideration.

After the political and economic transition, the Hungarian national economy could start to find the way towards the real market economy. A great number of newborn enterprises started their life in the 1990s, and it was not easy to find their way among the 
'western' circumstances. They had no well based institutional background and historical experiences. The managers of the new enterprises could get knowledge and find information about the management theories and practices used in the western countries, but much of these theories could not fit into the Hungarian economic environment and the Hungarian way of thinking.

The examined SMEs were all the 'children of the transition' - that means they were founded in the period of the political and economic changes of the 1990s - therefore their circumstances could be considered as nearly similar. The results of this survey described well the development stages of this group of enterprises. Salamonné in the cited study highlighted the correlations between the main features of different sized companies at different development phases. She concluded that only few organisations could reach the stage of dynamic growth during this period, therefore she suggested combining two stages of growth, namely 'Adolescence' and 'Prime'. By this change, the model could better reflect the local features of the Hungarian economy and the special conditions of the economic transition period.

These observations were drawn into further research and were published in another paper (Salamonné et al., 2008). According to the improved model, the developmental pattern of Hungarian SMEs can be visualised by a rising line with different breaks. This model is typical of Hungarian SMEs and we can find many differences when compared to the enterprises in western market economies. The authors recommended four lifecycle stages under the Hungarian economic circumstances, where the 1st stage is 'Starting', the 2nd is 'Uncontrolled growth', 3rd is 'Direction' (growth within formalised framework) and the last phase is 'Consolidation', where cooperation plays an important role (see Figure 3).

Figure 3 Lifecycle of Hungarian small and medium enterprises

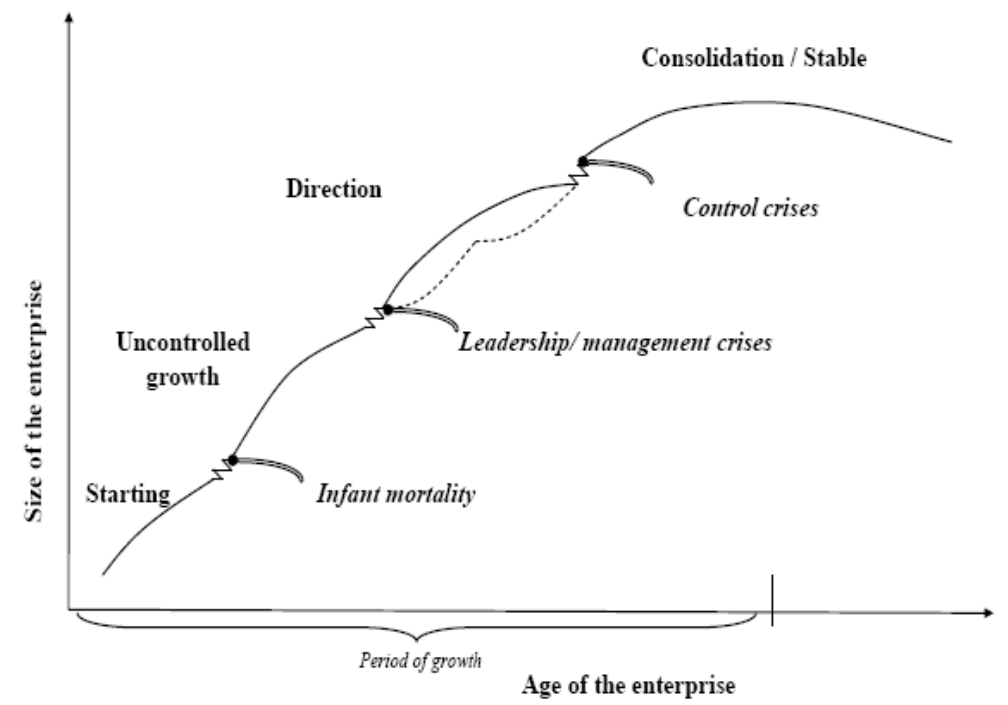

Source: Own construction based on Salamonné et al. (2008) 
Salamonné (2000, pp.185-186) also introduced a "profitability model based on the entrepreneur's attitudes". According to this model, a company which growth slows down - or with Adizes' words, when the Bureaucracy stage appears - may solve this problem by vertical expansion or product differentiation. The real solution is the reanimation of the former, more dynamic lifecycle phases. In case of small enterprises, the entrepreneur's spirit should be strengthened for this recovering for confirming or regaining the former position in the market competition.

Another Hungarian author, Rabi (2008) has conducted a survey among 22 successfully operated Hungarian SMEs, in which self-assessment questionnaires and in-depth interviews were used. According to Rabi, the development process of Hungarian SMEs may be well illustrated by the lifecycle model of Adizes.

The results of his survey showed that the peak of the lifecycle in small enterprises with 6-20 employees is close to the 'Go-go' stage, while larger SMEs, with 20-150 employees, can develop further, and the decline may be observed after 'Prime' stage. This trend is in compliance with the assumptions, because in smaller enterprises the managers have relatively too much power, which may lead to the lack of autonomy of the organisation which may be a barrier of the further development. In larger SMEs, the crisis in the 'Prime' stage is caused by the control problems, when the organisation is not prepared for the new challenges.

The evolution and the crisis may appear within each stage. When the managers can handle the situation, and they can manage the crisis, then the organisation is able to step into the next lifecycle stage, but, on the contrary, without the needed changes the organisation sooner or later will be terminated. The development of enterprises is mostly determined by their managers' attitudes for change; the lack of the ability for change will bring the death of the enterprise.

According to the observations of Bakonyi (2012), who followed the lifecycle of enterprises which were newly established in 2005 , only $40.5 \%$ of the observed enterprises were still operated in 2010. Bakonyi (2012) in a former work has given the following definition for new enterprises: enterprises may be considered as new, when it was operated in the given year, and was not operated in the previous two years. His results prove that development processes can easily turn out into the reverse direction, and may cause the decline on the organisation.

Illés et al. (2012) explored the different signs of evolution and revolution processes in the different lifecycle stages. They suggested to analyse the state of health of the enterprise and to identify the possible symptoms in the form of a 'corporate medical record'. This method, where the features of both the former and present lifecycle stages of the organisation are summarised, may be a very useful tool for company leaders, as the evolution and revolution features of the different stages could be well recognised by it. While evolution processes may help the company to remain in the given stage or to step into the next developmental stage, the revolutionary processes (or crises) may bring turbulent changes with negative impacts. The management of the revolutionary stages will principally determine the further development process of the company.

\section{Adaptation of Adizes' lifecycle model in our survey}

Based on the findings of different authors, we used the Adizes lifecycle model in our survey. In our opinion, this model may be considered as most detailed, because it gives 
the possible problems and refers to their solutions as well. In our present research, we used the full lifecycle model instead of the special Hungarian model, because the Hungarian enterprises could enter to the next changes as time has passed.

In our survey, we made some corrections of the original model; we substituted the original names of the stages into more descriptive, more practical titles, which can summarise the most important features and information about the enterprise. The sequence number of the lifecycle stages may be used as a scale as well, which made easier the data processing. The lifecycle model used in our survey is shown in Figure 4.

Figure 4 The adaptation of Adizes' lifecycle model in the questionnaire used in our survey

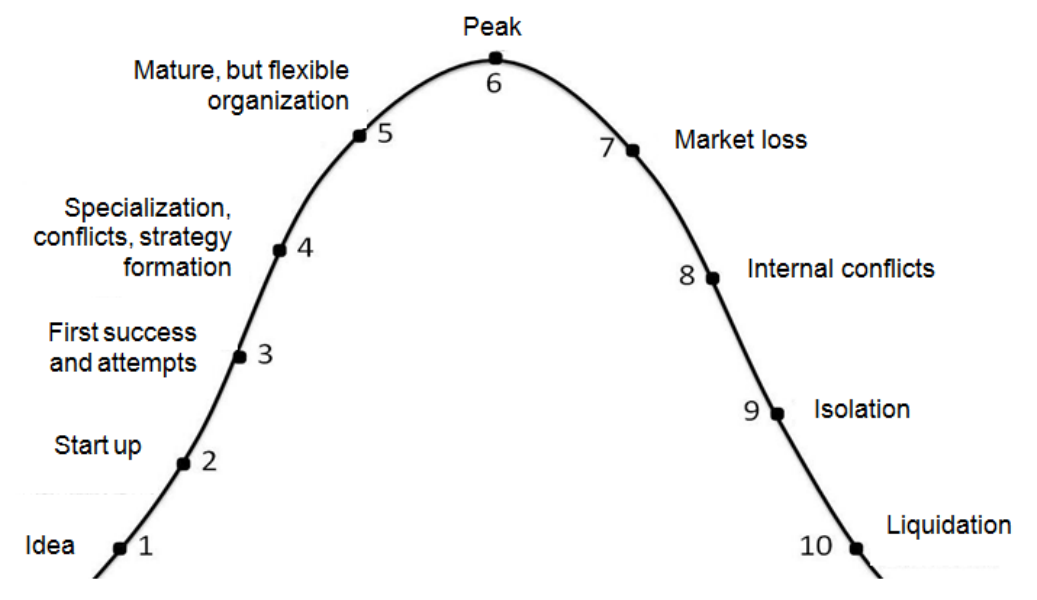

Source: Own compilation based on Adizes (1992, p.115)

In our research, we wished to explore whether the managers of the enterprises have different behaviour and attitudes in the different stages of the lifecycle, or not. The original lifecycle stages of the Adizes model were characterised according to this assumption.

In the 'Courtship' stage there only the idea that exists, some concepts and visions about the future enterprise. When somebody takes the risk, and starts the business, then the company will be born. If nobody will take the risk and the idea will not be followed by realisation, then the company will not start. In our survey, for understanding the essence of this stage more easily, we have given the name 'Idea'.

The stage 'Infancy' may be characterised by the increase of production and sales without any strategy. In this stage, the entrepreneurial spirit plays the most important role. Infant organisations need the constant need of food - i.e., operating capital - and the permanent care of the founders. The most significant problem is the loss of liquidity or if the founders lose their commitment. In our survey, we called this stage as 'Start up'.

The 'Go-go' stage is a very dynamic stage when the organisation successfully has passed the initial problems. The organisation - as the child who has just learned to walk moves quickly and interested in everything, planning is not the most important concept. The previous and present success has been generated by the risk-taking founder, and the risk easily may turn into failure. A larger organisation needs a different type of leader, who can delegate tasks to the colleagues, so as to be successful even without his/her presence. We called this stage as 'First success and attempts'. 
'Adolescence' is a stage full of confrontations; it is the organisation's teenager age, a very emotional time, where the enterprise must find a life apart from that the founders have provided. If the company can follow this way successfully, and will not fall into the trap of conflicts and distrust, then the organisation may establish a well-regulated system. According to our terminology, this is the period of "Specialization, conflicts and strategy formation". The growing of the size of the enterprise will not mean entering into the next stage; it is depending on the regulatory system of the organisation. While in the initial stage the idea and the new product was the most significant objective of the enterprise, in this stage the emphasis shifts towards the more precise operation process and successful sales.

'Prime' stage is the optimal position on the lifecycle, where the organisation finally achieves a balance between control and flexibility, and it has all the advantages of adolescence and prime stages. The control works well; the creativity is adaptable and very dynamic. According to our assumption, it is the stage of "Mature, but flexible organization". This stage is the optimum point of the lifecycle, and the management must proactively work to promote activities that retard ageing and sustain the vitality of this stage. Continuous innovation is needed in this period.

'Stable' phase means that the vitality of the organisation is at its maximum, it is strong, but it is starting to lose its flexibility and innovativeness. For the renewal new ideas, dynamic and very strong entrepreneurial spirit would be needed, and with lack of this spirit the enterprise will be too comfortable will start to decline. In our questionnaire, we referred to this period as 'Peak', which has both positive and negative meaning.

'Aristocracy' is in the declining part of the lifecycle curve. The ageing of the enterprise is not resulted by passing of time or decreasing of the size of the company, but rather by losing the flexibility of operation and the lack of ability for renewal. Nevertheless, the organisation may grow in size in this period, but the operations are managed routinely. The number of buyers starts to decrease, which will lead to revenue and profit losses. We called this stage as 'Market loss'.

In 'Early bureaucracy' the signs of bureaucracy occur, with huge administrative burden and internal conflicts. The people do not trust in each other and the risk avoiding attitude spreads. The name of this period was called 'Internal conflicts'.

In 'Bureaucracy' stage the emphasis is on administration, the company becomes introverted, inflexible and unmanageable, therefore we called this stage 'Isolated'.

'Death' is the end of the corporate lifecycle, the enterprise is not able to exist, it is liquidated, therefore we used the name 'Liquidation'.

\section{Material and methods}

According to our assumption, the age of the enterprise (i.e., the position on the lifecycle curve) strongly determines corporate efficiency. For the verification of this hypothesis, we conducted a survey. The research was based on the primary data of an online survey sent in September 2012. The survey was fulfilled by 241 top managers. This means that answers represented subjective opinions.

Full representativeness could not be an objective of this research, but it should be noted that the responses resembled a similar picture to the Central Statistical Office statistics on size distribution of domestic enterprises. 
Statistical analysis was performed with SPSS for Windows Programme package. After coding the questionnaires and recording the answers labels were given. Descriptive statistics was used in the initial steps, to present the frequencies of the answers to the respective questions.

Associative links between qualitative variables were examined by crosstabs; the statistical significance of links was tested by chi-square $\left(\chi^{2}\right)$ test. The null hypothesis was that the variables were independent; the null hypothesis was refused if the empirical significance values were not larger than $5 \%$. Refusal of the null hypothesis meant the statistical justification of an associative link.

Strength of correlation between two ordinal variables was tested by the Gamma association test, which is a symmetric measure of association between two ordinal variables which range is between -1 and 1 . Values close to an absolute value of 1 indicate a strong relationship between the two variables. Values close to zero indicate little or no relationship. Negative sign shows a relationship of opposite direction, a higher value of one variable indicates a probably lower value for the other variable.

If two nominal or mixed (nominal and ordinal) variables were tested for correlation, then the Cramer's V was applied. Cramer's V is a measure of association based on chi-square, its value can range between 0 and 1 , a value closer to 1 indicates stronger relationship.

From multivariate statistical tests, we applied cluster analysis to group observed units and variables.

For grouping variables we used hierarchical clustering, as agglomeration methods we used the nearest neighbour and Ward's variance method. The first methods is perfect to indicate extreme cases, the Ward method maximises in-cluster similarity. Dendograms were used to display the results, and the resulting graph allowed identifying and denominating the groups.

For grouping observed units, the K-means clustering was used.

In the formulation of the groups, we considered the deviation of the group average as the basis for classification. For this one-way analysis of variance (ANOVA) was used. We tested the differences between the group averages by the empirical significance values ( $\mathrm{p}$-values). Differences are statistically significant if the $\mathrm{p}$-values are not larger than $5 \%$.

We used post hoc tests to identify groups with significantly deviating averages. Analysis of variation was tested with the Levene-method to identify the proper post hoc test. If the variances were identical between groups then the Turkey and Scheffe test was used, otherwise the Games-Howell test was applied.

\section{Results}

In the examination of the efficiency of enterprises in our sample, we analysed the data of the balance sheets and assessed the number of employees, the revenue and the balance sheet total data, as the most important indicators of growth. Furthermore, from the available data we calculated selected efficiency [asset efficiency (AE)] and profitability indicators (ROA, i.e., return on assets and ROS, i.e., return on sales). We summarised the used indicators and their calculation methods in Table 1. 
Table 1 Calculation methods of the used efficiency and profitability indicators

\begin{tabular}{lc}
\hline $\begin{array}{l}\text { Asset efficiency } \\
\text { (asset turnover) }\end{array}$ & $\mathrm{AE}=\frac{\text { Revenue }}{\text { Total assets }}$ \\
\hline Return on assets & ROA-I $=\frac{\text { Net income }}{\text { Total assets }}$ \\
& ROA-II $=\frac{\text { Earnings before taxes }}{\text { Total assets }}$ \\
\hline Return on sales & ROS-I $=\frac{\text { Net income }}{\text { Revenue }}$ \\
ROS-II $=\frac{\text { Earnings before taxes }}{\text { Revenue }}$ \\
\hline
\end{tabular}

\section{Source: Own construction}

The classification of enterprises by efficiency can be done in multiple ways. Our objective was to classify the enterprises in such way by which it is possible to diminish the absolute size differences and consider growth and profitability indicators simultaneously. The solution which we found was identifying the principal components of annual growth (number of workforce, revenue, and balance sheet total) and the annual $\mathrm{AE}$ and selected profitability indicators (ROA, ROS). The average growth of the principal components was calculated with the ordinary least squares (OLS) method, which gives estimation by minimising deviation sums of squares. This method evens out deviations of alternate directions and gives a larger weight to larger deviations by counting the square.

Hierarchical clustering with the 'nearest neighbour' method did not provide any proof for similarity of $\mathrm{AE}$ and other variables for the examined years. The principal component analysis confirmed that the communality of this variable did not reach the minimally necessary level (0.350) [Sajtos and Mitev, (2007), p.268].

For the assessment, we filtered the original database and only those enterprises were chosen which were at least five years old. However, in some cases a missing interim value caused that no principal component was generated for the given enterprise. Finally, we classified the 194 enterprises having all the necessary data into four categories by the 'Growth' and 'Profitability' principal components (dimensions).

Those enterprises, which showed positive values for both variables ('Growth' and 'Profitability') were titled 'Competitive'. The enterprises that only grew in size were titled 'Showing growth'. Companies that did not grow but their revenues have indicated profitability was called as 'Profitable'. Finally, those enterprises, which showed decline in both indicators were classified as 'Non-competitive'.

The different groups and their number in the sample are summarised in Table 2.

Table 2 Main features of the different groups in the sample

\begin{tabular}{lccc}
\hline Growth & Profitability & Name of the group & Number in sample \\
\hline+ & + & Competitive & 45 \\
+ & - & Showing growth & 46 \\
- & + & Profitable & 54 \\
- & - & Non-competitive & 49 \\
\hline
\end{tabular}

Source: Own construction 
The distribution of the examined enterprises is visualised in Figure 5, according to the four subcategories.

Figure 5 Distribution of enterprises by the dimensions of 'growth' and 'profitability' (see online version for colours)

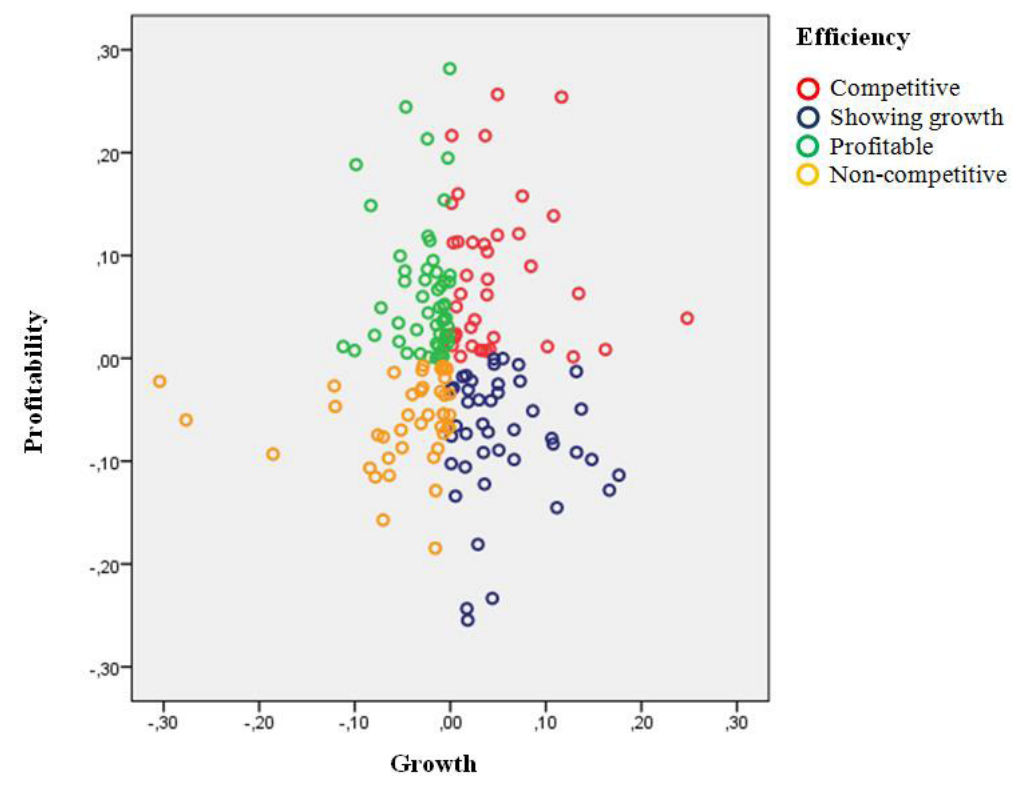

Source: Own construction

We used multiway variance analysis for assessing that the four subcategories can or cannot be distinguished significantly according to the two principal components (i.e., growth and profitability). The statistical analyses verified that there is a significant difference between the profitability indicators in the different groups $(\mathrm{F}=28,392$; $\mathrm{p}<0,001$; Wilks-Lambda distribution $=0.475$; partial $\varepsilon^{2}=0.311$ ). The further analyses confirmed that in case of 'Growth' indicator the results are not significant because of the significance level of Levene test $(p<0.001)$. The impact of 'Profitability' is significant according to the statistical analysis $\left(F=32,662 ; p<0.001\right.$; partial $\left.\varepsilon^{2}=0.340\right)$. According to the 'Profitability' component the categories may be distinguished significantly, while 'Competitive' and 'Profitable' subcategories showed the same high results $(p=0.378)$, the 'Non-competitive' and 'Showing growth' categories showed low values $(p=0.804)$ according to this indicator.

Based on the attributes of the enterprise according to their position in the lifecycle there was no significant difference between efficiency categories using crosstab analysis.

We applied multivariate logistical regression to check for the connection between enterprise attributes (headcount category, age, location, lifecycle position, Porterian strategy) and efficiency categories but no significant correlation emerged $(p=0.200)$.

Using multivariate variance analysis to examine corporate attributes statistically significant difference could be seen in 'Profitability'. Additional analyses showed that lifecycle position had significant distinguishing effect on 'Profitability' $(p=0.009)$. Post hoc tests could not been conducted, because - at least in one of lifecycle stages - less 
than two cases could be found. Nevertheless, the effects of lifecycle variables on the profitability were significant, and it was confirmed by the statistical analyses.

Furthermore, the correlation between the 'Growth' indicator and the age of the enterprise was verified by statistical analyses. According to its results, the connection is a weak negative correlation $(p=0.002$; Spearman's $\rho=-0.226)$, which means that the ageing process of the enterprises will decrease their rate of growth. This underlines the natural process of adjustment to a saturation level. The initial accelerating growth is followed by saturation, which slows the growth down. The market can be saturated with the given product (Vernon, 1966) if the company cannot react for the changes of the market circumstances in a flexible way or it is not able to innovate. This can be followed by a decline (Adizes, 1992) even if the product may be kept as profitable for a while as a result of the mature and well used technology and the low input cost level.

\section{Conclusions}

Nowadays companies are growing larger and larger, the markets are turning into global markets, and the technological development is increasing extremely. The consumers' demand also has been transformed; they need more and more products, more quickly in better and better quality. The competition is very hard. Companies must accept this new trend, and they shall adapt to the turbulently changing business environment (Szentes, 2011).

The challenges may be turned both into opportunities and threats. The opportunities of today may be turned into threats tomorrow. When competitors can take the advantages of a situation using their opportunities - for example, they can reduce their costs - the companies must take the necessary steps immediately. The previously detected opportunities - as a result of the changing environment - may be turned into constraints, which may generate crisis (Bögel and Salamonné, 1998). Lifecycle models may be an effective tool for exploring these processes.

In this paper, we collected the different lifecycle analyses according to the international and Hungarian literature. We used Adizes' lifecycle model for our research, which goal was to determine the present position of Hungarian enterprises in their lifecycle and to prove that the most important indicators of growth are in connection with the position of the enterprise in its own lifecycle.

Of course, it is very complex problem to recognise the particular lifecycle stage of an enterprise, as the differences between stages in most cases are not separated by sharp lines. Therefore, we adapted the Adizes model in our questionnaires and we characterised the different stages with more practical phrases and descriptions.

In the future, we consider following our researches by using the model of Greiner (1998), because this model concentrates on growth, and the different stages of his model are given according to the size and the age of the organisation. A recent Hungarian research (Miskolczi, 2012) was conducted according to this model based on the data of Hungarian SMEs operated in trading and manufacturing industry. The results of the research, which was based on the survey of the top managers of the examined enterprises, have proven that the Hungarian SMEs may be assessed according to the phases given by the model of Greiner. 


\section{References}

Adizes, I. (1992) 'Vállalatok életciklusai: Hogyan és miért növekednek és halnak meg vállalatok, és mi az ezzel kapcsolatos teendő?, pp.1-350, HVG Kiadó, Budapest.

Bakonyi, P. (2011) Müködö, valódi új, valódi megszünt vállalkozások száma létszám-kategóriák szerint (1999-2009), 26 May, KSH, Budapest [online]

http://www.ksh.hu/docs/hun/modsz/modsz32.html (accessed 24 July 2012).

Bakonyi, P. (2012) 'Vállalkozások demográfiája, 2010', Statisztikai tükör, Vol. 34, pp.1-4, KSH, [online] http://www.ksh.hu/docs/hun/xftp/idoszaki/valldemog/valldemog10.pdf (accessed 24 July 2012).

Bőgel, G. and Salamonné, H.A. (1998) Vállalatvezetés felsőfokon, pp.1-255, Kossuth Kiadó, Budapest.

Greiner, L.E. (1972) 'Evolution and revolution as organizations growth', Harvard Business Review, Vol. 50, No. 4, pp.37-46.

Greiner, L.E. (1998) 'Revolution is still inevitable', Harvard Business Review, Vol. 76, No. 3, pp.64-65.

Illés, B.C., Dunay, A. and Tatár, E. (2012) 'Lifecycle analysis at small and medium enterprises: theory and practice', in Illés, C.B. (Ed.): SMEs' Management in the 21st Century: Challenges and Solutions, 424pp, Chapter 1.2, pp.41-53, Faculty of Management of the Czestochowa University of Technology, Czestochowa.

Miskolczi, M. (2012) vállalatnövekedési modellek besorolási módszere vállalatok logisztikai szervezeteinek vizsgálatához, PhD értekezés, $187 \mathrm{pp}$, Szent István Egyetem, Gödöllő.

Rabi, S. (2008) 'Kis-és középvállalkozások a szervezeti életciklus modell tükrében II', Cégvezetés [online] http://www.ugyvezeto.hu/cikk/54200/a-kis-es-kozepvallalkozasok-a-szervezetieletciklus-m\%20\%20odell-tukreben-ii-resz?wa=eugy0839h (accessed 11 January 2011).

Sajtos, L. and Mitev, A. (2007) SPSS kutatási és adatelemzési kézikönyv, pp.1-404, Alinea Kiadó, Budapest.

Salamonné, H.A. (2000) Jövőkép és stratégia alkotás, pp.1-207, Kossuth Kiadó, Budapest.

Salamonné, H.A. (2006) 'Magyarországi kis-és középvállalkozások életútjának modellezése', Competitio $V$, évfolyam 1, szám 2006/3, pp.51-68.

Salamonné, H.A., Illés, B.C., Kozma, T. and Horányi, B. (2008) 'Developmental cycles and strategies of small and medium sized enterprises in Hungary', in Aktan, C. and Dalbay, O. (Eds.): Selected Proceedings of the First International Conference on Social Sciences: 'Management and Behaviour in Organisations', Vol. 2, pp.145-156, Social Sciences Research Society, Izmir.

Szentes, T. (2011) Fejlödés-gazdaságtan, pp.1-531, Akadémiai Kiadó, Budapest.

Timmons, J. (1990) New Venture Creation: Entrepreneurship in the 1990s, 3rd ed., 704pp, Richard D. Irwing, Homewood, IL.

Vernon, R. (1966) 'International investment and international trade in the product lifecycle', The Quarterly Journal of Economics, Vol. 80, No. 2, pp.190-207.

\section{Websites}

http://adizes.com. 